\title{
Penerapan Metode Latis untuk Mengurangi Kesalahan Siswa dalam Operasi Perkalian Ditinjau dari Kemampuan Awal Siswa
}

\author{
Rifkah Chaerunnisa $\mathrm{M}^{1, \text { a) }}$, Suradi $^{1, \mathrm{~b})}, \mathrm{Asdar}^{1, \mathrm{c})}$ \\ ${ }^{1}$ Jurusan Matematika FMIPA Universitas Negeri Makassar, 90224 \\ a) rifkahchaerunnisam@gmail.com \\ b)suradi@gmail.com \\ c)asdarku@gmail.com
}

\begin{abstract}
Abstrak. Penelitian ini bertujuan untuk mengurangi kesalahan siswa dalam operasi perkalian dengan menerapkan metode perkalian latis. Jenis penelitian ini adalah penelitian kualitatif dengan metode Penelitian Tindakan Kelas (PTK). Subjek penelitian adalah 24 siswa yang dipilih secara purposive. Penelitian dilaksanakan di kelas VII dari salah satu SMP di Parepare. Tahun ajaran 2018/2019. Intrumen penelitian yang digunakan terdiri atas lembar observasi, soal tes, dan angket. Desain PTK menggunakan model Kemmis dan Tanggart yang meliputi perencanaan, tindakan/pelaksanaan, observasi, dan refleksi. Hasil penelitian menunjukkan bahwa Skor rata-rata hasil tes matematika siswa setelah pemberian tindakan pada siklus I adalah 58,33 dari skor ideal 100 dan sebanyak 15 siswa yang melakukan kesalahan dalam operasi perkalian. Sedangkan skor rata-rata hasil tes matematika siswa setelah pemberian tindakan pada siklus II adalah 80,83 dari skor ideal 100 dan sudah tidak ada lagi siswa yang melakukan kesalahan. Kesalahan siswa dalam menyelesaikan soal operasi perkalian bilangan bulat dan bilangan pecahan desimal terdapat tiga aspek kesalahan yaitu kesalahan dalam memahami konsep, kesalahan proses penyelesaian, dan kesalahan penarikan kesimpulan. Sehingga dapat disimpulkan bahwa penerapan metode latis dapat mengurangi kesalahan siswa dalam operasi perkalian ditinjau dari kemampuan awal siswa SMP di Parepare
\end{abstract}

Kata kunci: Kesalahan siswa, Operasi perkalian, Metode latis, Kemampuan Awal, PTK

\begin{abstract}
This research aims to reduce the students error in multiplication operation by implementing latis multiplication method. Type of research is qualitative research by classroom action research methods. Research subject are 24 students which selected by purposive which is encountered errors in multiplication operations. This research conducted in class VII.1of on SMP in Parepare Academic year 2018/2019. Classroom action research design by using Kemmis and Tanggart model which includes planning action/ implementation, observation and reflection. The result of research shows that the average score of math test results after giving the action in Cycle is 58.33 from ideal score 100 and there are 15 students which make a mistake in operation the multiplication. While the average score of math test result after giving the action in cycle ii is 80.83 from ideal score 100 and there is no more student that make a mistake. Students error in solving integer multiplication and decimal fraction operation problems there are three error aspects that are in understanding the concept, error solving process and error of inference. So that, it can be conclude that the implementation of latis method can reduce the student error in multiplication operation in terms of the initial abilities of students SMP in Parepare.

Keywords: Student errors, multiplication operation, latis method, initial ability, classroom action research
\end{abstract}




\section{PENDAHULUAN}

Matematika mempunyai peranan penting dalam perkembangan ilmu pengetahuan teknologi. Karakteristik matematika yang abstrak dan sistematis menjadi salah satu alasan sulitnya siswa mempelajari matematika. meskipun demikian kenyataan yang terjadi di sekolah menunjukkan bahwa siswa tidak menyukai matematika karena dianggap sebagai bidang studi yang paling sulit diantara bidang studi lainnya. Hal ini disebabkan karena rendahnya keterampilan berfikir siswa sehingga menyebabkan kesalahan-kesalahan dalam menyelesaikan masalah matematika.

Masalah matematika tingkat SMP terletak pada rendahnya rasa ingin tahu siswa dan kemauan untuk memecahkan masalah tersebut, apalagi kalau sampai tidak pernah mereka pelajari sebelumnya. Ketika hal ini terbentuk dalam benak siswa, bukan tidak mungkin bagi mereka matematika adalah sesuatu yang sulit dipahami. Pada hal matematika sebagai salah satu mata pelajaran penting, bukan hanya karena wajib diberikan di sekolah, tetapi jumlah pekerjaan bergantung pada bagus atau tidak pemahaman dasar matematika.

Permasalahan yang dihadapi siswa adalah lemahnya kemampuan siswa dalam operasi perkalian dan lemahnya kemampuan menghapal perkalian dasar. Siswa banyak melakukan kesalahankesalahan dalam operasi perkalian sehingga setiap siswa harus memahami dan menguasai konsep operasi perkalian sehingga tidak mengalami kesalahan dalam berhitung. Salah satu letak kesalahan siswa dalam menyelesaikan soal perkalian adalah kesalahan memahami soal dan kesalahan kecerobohan, dimana kesalahan yang dilakukan siswa tidak berhati-hati, atau tidak teliti dalam menyelesaikan soal operasi hitung dan siswa kurang cermat dalam menyelesaikan soal serta kesulitan mengalikan bilangan bulat dan desimal yang besar.

Hasil observasi diperoleh bahwa masih terdapat siswa yang tidak bisa menentukan hasil hitung perkalian bilangan. Dimana siswa tidak mampu menggunakan perkalian bersusun secara benar untuk menyelesaikan perkalian. Umumnya siswa mengalami kesalahan dalam mengalikan dan menyimpan. Apabila siswa kurang teliti dalam angka yang sudah disimpan maka hasil perkaliannya salah. Oleh karena itu, perlu adanya upaya lain untuk mengatasi siswa yang belum menguasai perkalian dengan metode bersusun.

Upaya yang dapat mengatasi adalah munculnya berbagai metode dalam perkalian bilangan asli. Metode tersebut diantaranya adalah metode jarimatika, metode perkalian bersusun, dan metode perkalian latis. Salah satu metode yang menarik adalah metode perkalian latis. Metode perkalian Latis adalah metode perkalian yang disajikan dalam bentuk tabel yang memuat hasil perkalian. Hasil perkalian dua bilangan ditempatkan dalam tabel yang disusun berdasarkan satuan, puluhan, ratusan dan seterusnya.

Terdapat beberapa penelitian yang berkaitan dengan penerapan metode latis terhadap kesalahan siswa (Djadir \& Darwis, 2016; Ugi, 2016; Mujib \& Suparingga, 2013; Panji, 2017; Zubaidah \& Hery, 2015; Rafiq, 2011; Soedjadi, 2013). Ugi (2016) meneliti tentang kesalahan siswa pada operasi hitung campuran bilangan bulat. Adapun Mujib \& Suparingga (2013) meneliti tentang upaya mengatasi kesulitan siswa dalam operasi perkalian dengan metode latis.

Penelitian ini berfokus pada penerapan metode latis untuk mengurangi kesalahan siswa dalam operasi perkalian. Subjek pada penelitian ini yaitu siswa kelas VII SMP. Penelitian ini bertujuan untuk mengurangi kesalahan siswa dalam operasi perkalian dengan menerapkan metode perkalian latis.

\section{KAJIAN PUSTAKA}

Kesalahan merupakan penyimpangan terhadap hal yang benar yang sifatnya sistematis, konsisten, maupun insedental pada aderah tertentu. Kesalahan-kesalahan secara umum dapat diartikan sebagai suatu kondisi dalam proses belajar yang ditandai dengan hambatan-hambatan 
tertentu untuk mencapai hasil belajar, sehingga prestasi belajar yang dicapai berada dibawah yang semestinya (Djadir \& Darwis, 2016)

Adapun kesalahan-kesalahan dalam menyelesaikan soal matematika (Soedjadi, 2013) yaitu: (1) Kesalahan fakta; (2) Kesalahan konsep; (3) Kesalahan prinsip; dan (4) Kesalahan Operasi. Kesalahan yang dilakukan siswa dalam operasi perkalian yaitu kesalahan dalam menentukan hasil operasi hitung perkalian; kesalahan dalam menulis ulang soal, jawaban tanda, operasi hitung; dan kesalahan dalam menentukan langkah-langkah penyelesaian soal.

Metode latis merupakan suatu metode alternatif yang dapat diberikan kepada siswa untuk memudahkan siswa dalam operasi perkalian (Mujib \& Suparingga, 2013). Rafiq (2011) berpendapat bahwa perkalian metode latis adalah suatu cara hitung dalam perkalian untuk memperoleh hasil perkalian dengan membuat sebuah garis berbentuk kotak sebagai jalan hitung perkalian. Maka dapat disimpulkan bahwa metode latis adalah suatu metode yang disajikan dalam bentuk tabel/kotak untuk mempermudah siswa dalam berhitung dan mengurangi kesalahan berhitung.

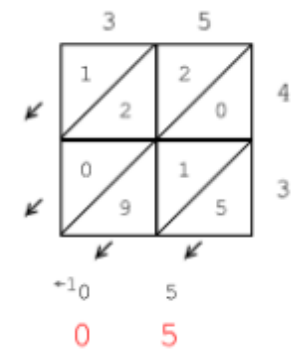

GAMBAR 1. Perkalian Metode Latis

Gambar 1 merupakan perkalian metode latis yang hasil perkalian dua bilangan ditempatkan dalam tabel yang disusun berdasarkan satuan dan puluhan. Bagian garis diagonal atas diisi dengan angka puluhan dan diagonal bawah diisi dengan angka satuan (Mujib \& Suparingga, 2013).

Metode perkalian latis adalah perkalian yang menggunakan grid dalam berhitung. Dalam grid tersebut ada kisi atau pembatas berupa garis diagonal yang membagi satu kotak menjadi tempat puluhan dan satuan hasil kali (Panji, 2017).

\section{METODE PENELITIAN}

Penelitian ini merupakan penelitian tindakan kelas yang dilakukan secara bersiklus. Penelitian tindakan ini dilaksanakan dua siklus. Setiap siklus terdiri dari 4 tahap, yaitu: (1) perencanaan, (2) tindakan, (3) observasi dan evaluasi, dan (4) refleksi. Penelitian ini dilaksanakan di kelas VII dari salah satu SMP di Parepare. Subjek penelitian yang dipilih secara purposive yaitu siswa yang mengalami kesalahan-kesalahan dalam operasi perkalian.

Gambar 2 merupakan bagan model PTK menurut Kemmis dan Mc. Tanggart (2000). Dimulai dari perencanaan, pelaksanaan, observasi, dan refleksi. Hasil dari refleksi adalah revisi terhadap perencanaan yang telah dilaksanakan pada pertemuan selanjutnya.

Teknik pengumpulan data dalam penelitian ini adalah tes, observasi, dan angket. Instrumen yang dikembangkan adalah lembar observasi siswa, pre-test, post-test dan angket. Data yang diperoleh adalah data kualitatif yaitu dari observasi siswa dan guru melalui lembar observasi dan angket, sedangkan data kuantitatif dari hasil belajar siswa pada akhir siklus pembelajaran. 
Pengambilan data dilakukan dengan cara pengambilan tes kemampuan awal diberikan post-test. Data mengenai situasi pembelajaran pada saat pelaksanaan tindakan, diperoleh melalui pengamatan pada saat kegiatan berlangsung dengan menggunakan lembar observasi. Data mengenai hasil belajar siswa dengan menggunakan tes pada akhir siklus. Data mengenai respon siswa dikumpulkan dengan menggunakan angket. Dan data tentang kesalahan-kesalahan siswa sebelum pemberian tes dan tindakan.

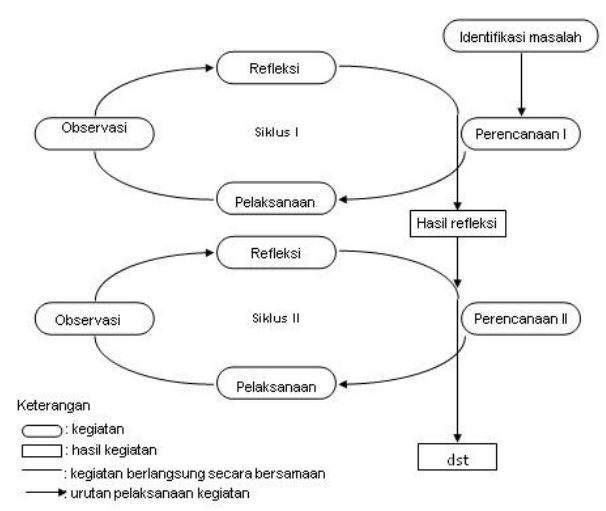

GAMBAR 2. Bagan Model PTK

\section{HASIL PENELITIAN DAN PEMBAHASAN}

Penelitian ini dilaksanakan sebanyak dua siklus. Setiap siklus dilaksanakan sebanyak tiga kali pertemuan dengan materi menyesuaikan pada kondisi pembelajaran. Penelitian ini merupakan suatu kolaborasi antara peneliti dengan guru dalam menerapkan metode latis

\section{Siklus I}

Pada tahap perencanaan, penelitian ini mengembangkan intrumen. Intrumen yang dikembangkan adalah pre-test, psot-test, lembar observasi, dan angket. Selain itu juga menyiapkan sampel. Intrumen ada dua yaitu instrumen pembelajaran dan instrumen penelitian. Intrumen yang dikembangkan adalah RPP, pre-test, post-test. Lembar observasi, dan angket. Intrumen tersebut telah divalidasi dan diperbaiki. Dalam perencanaannya peneliti menetapkan pokok bahasan, dan menyiapkan materi pembelajaran yang berupa perkalian. Selain itu, ada diskusi dengan guru kelas yang mengajarkan matematika di sekolah ini.

Pada tahap pelaksanaan, pembelajaran diawali dengan berdoa bersama, menyampaikan tujuan pembelajaran. Selanjutnya memberikan penjelasan tentang materi dengan menerapkan metode latis dengan cara menggali kemampuan awal siswa dengan bertanya tentang perkalian. Pada tahap ini guru melaksanakan pengajaran dengan menggunakan RPP dan memberikan lembar kerja kepada siswa untuk melakukan diskusi dan menyimpulkan hasil diskusinya. Selanjutnya memberikan kesempatan kepada siswa untuk bertanya apabila ada yang belum dipahami mengenai materi. Respon siswa terhadap metode perkalian ini bagus dan memotivasi untuk bersungguh-sungguh dalam belajar.

Pada tahap observasi dan evaluasi dilakukan untuk mengetahui sejauh mana keterlaksanaan pembelajaran dan bagaimana aktivitas siswa selama pembelajaran matematika dengan menerapkan metode latis. Pada tahap ini dilaksanakan proses observasi terhadap pelaksanaan tindakan dengan menggunakan lembar observasi. Adapun yang diobservasi pada siswa yaitu keaktifan siswa, kedisiplinan, penugasan/resitasi siswa. Evaluasi yang diberikan pada akhir siklus berupa tes hasil belajar siswa terhadap penerapan metode latis. 
Berdasarkan hasil jawaban siswa dalam mengerjakan soal-soal pada materi operasi perkalian bilangan bulat dan bilangan pecahan tersebut terdapat beberapa kesalahan yang dilakukan oleh beberapa siswa dan hasil evaluasi dapat dilihat pada Tabel 1:

TABEL 1. Hasil Observasi Siklus I

\begin{tabular}{ccc}
\hline No & Uraian & Nilai \\
\hline 1 & Nilai Terendah & 20 \\
2 & Nilai Tertinggi & 90 \\
3 & Nilai Rata-rata & 58,33 \\
\hline
\end{tabular}

Pada Tabel 1 menunjukkan bahwa hasil observasi awal pada saat siklus I dalam operasi perkalian pada siswa kelas VII dengan jumlah nilai terendah 20 yaitu siswa yang belum tuntas dan melakukan kesalahan dan nilai tertinggi 80 yaitu siswa yang tuntas dan tidak melakukan kesalahan dari nilai ideal 100 dengan nilai rata-rata 58,33.

TABEL 2. Jumlah Siswa yang Melakukan Kesalahan Siklus I

\begin{tabular}{lc}
\hline \multicolumn{1}{c}{ Keterangan } & Persentase \\
\hline Jumlah Siswa Yang Tuntas & 11 \\
Persentase Ketuntasan & $45,8 \%$ \\
Jumlah Siswa Tidak Tuntas & 13 \\
Persentase Ketidaktuntasan & $54,1 \%$ \\
\hline
\end{tabular}

Pada Tabel 2 merupakan jumlah siswa yang melakukan kesalahan Siklus I. Maka diperoleh bahwa masih terdapat siswa yang melakukan kesalahan dalam menentukan hasil hitung perkalian bilangan. Dari 27 siswa, sebanyak 24 siswa yang melakukan kesalahan. Oleh karena itu, dalam pembelajaran matematika menggunakan metode latis ternyata hasilnya belum memuaskan. Nilai yang diperoleh pada siklus I siswa yang tuntas $45,8 \%$ dan tidak tuntas $54,1 \%$. Sehingga nilai rata-rata yaitu 58,33.

Pada tahap refleksi dapat dilihat bahwa kurangnya perhatian siswa dan kurang pahaman dengan metode latis. Diperoleh bahwa terdapat 15 siswa yang masih mengalami kesalahan. Sebanyak 13 siswa yang belum tuntas dan 2 siswa yang sudag tuntas. Berdasarkan hasil perolehan dari siklus I maka guru merencanakan perbaikan pembelajaran pada siklus II dengan menggunakan metode latis.

\section{Siklus II}

Pada tahap perencanaan, siklus II pada dasarnya mengulang langkah-langkah pada siklus 1 , namun yang berbeda adalah pada siklus II dilakukan penyempurnaan dan perbaikan terhadap kendala yang muncul pada siklus I.

Pada tahap pelaksanaan, sama halnya dengan siklus I yaitu berdoa bersama dan menyampaikan tujuan pembelajaran. Akan tetapi, siklus II lebih difokuskan pada tindakan-tindakan baru yaitu memperjelas materi pokok yang akan dijelaskan secara rinci disertai dengan contoh dan membimbing langsung siswa yang masih masih kesulitan memahami materi yang dibahas. Pada tahap ini guru melaksanakan pengajaran dengan menggunakan RPP dan memberikan lembar kerja kepada siswa untuk melakukan diskusi dan menyimpulkan hasil diskusinya. Respon siswa terhadap metode perkalian ini bagus dan memotivasi untuk bersungguh-sungguh dalam belajar.

Pada tahap observasi dan evaluasi dilakukan untuk mengetahui sejauh mana keterlaksanaan pembelajaran dan bagaimana aktivitas siswa selama pembelajaran matematika dengan menerapkan metode latis. Pada tahap ini dilaksanakan proses observasi terhadap pelaksanaan tindakan dengan menggunakan lembar observasi. Adapun yang diobservasi pada siswa yaitu keaktifan siswa, kedisiplinan, penugasan/resitasi siswa. Evaluasi yang diberikan pada akhir siklus berupa tes hasil belajar siswa terhadap penerapan metode latis. 
Berdasarkan hasil jawaban siswa dalam mengerjakan soal-soal pada materi operasi perkalian bilangan bulat dan bilangan pecahan tersebut terdapat beberapa kesalahan yang dilakukan oleh beberapa siswa dan hasil evaluasi dapat dilihat pada tabel 3:

TABEL 3. Hasil Observasi Siklus II

\begin{tabular}{ccc}
\hline No & Uraian & Nilai \\
\hline 1 & Nilai Terendah & 70 \\
2 & Nilai Tertinggi & 90 \\
3 & Nilai Rata-rata & 80,83 \\
\hline
\end{tabular}

Pada Tabel 3 menunjukkan bahwa hasil observasi awal pada saat siklus II dalam operasi perkalian pada siswa kelas VII dengan jumlah nilai terendah 70 yaitu siswa yang belum tuntas dan nilai tertinggi 80 yaitu siswa yang tuntas dari nilai ideal 100 dengan nilai rata-rata 80,83. Jumlah siswa yang belum tuntas dan melakukan kesalahan sudah tidak ada. Berdasarkan yang diamati menunjukkan bahwa keberhasilan pelaksanaan penelitian ini adalah terjadinya peningkatan skor rata-rata belajar matematika yang diperoleh siswa.

TABEL 4. Jumlah Siswa yang Melakukan Kesalahan Siklus II

\begin{tabular}{lc}
\hline \multicolumn{1}{c}{ Keterangan } & Persentase \\
\hline Jumlah Siswa Yang Tuntas & 24 \\
Persentase Ketuntasan & $100 \%$ \\
Jumlah Siswa Tidak Tuntas & 0 \\
Persentase Ketidaktuntasan & $0 \%$ \\
\hline
\end{tabular}

Pada Tabel 4 merupakan jumlah siswa yang melakukan kesalahan siklus II. Maka diperoleh bahwa keberhasilan pelaksanaan penelitian ini adalah terjadinya peningkatan belajar matematika yang diperoleh siswa. Terlihat bahwa semangat siswa untuk belajar semakin memperlihatkan kemajuan setelah diterapkan metode perkalian latis dan dapat dikatakan bahwa hasil yang diperoleh siswa mengalami peningkatan jika dibandingkan dengan tes yang dilaksanakan diakhir siklus I.

Pada tahap refleksi dilakukan setelah melakukan tindakan pada siklus II. Dari data yang diperoleh selama observasi di siklus II bahwa terjadinya peningkatan skor rata-rata belajar matematika yang diperoleh siswa. Dari hasil penelitian diperoleh nilai rata-rata sebesar 80,83 sebanyak 24 siswa mendapat nilai $\geq 70$, dan jumlah siswa yang belum tuntas dan melakukan kesalahan sudah tidak ada.

\section{KESIMPULAN}

Terjadinya peningkatan yang cukup signifikan dari hasil pembelajaran matematika sebagai dampak adanya peningkatan hasil belajar dengan menggunakan metode latis pada siswa kelas VII. Kesalahan siswa dalam menyelesaikan soal operasi perkalian bilangan bulat dan bilangan pecahan desimal terdapat tiga aspek kesalahan yaitu kesalahan dalam memahami soal, kesalahan dalam menerapkan konsep untuk menyelesaikan permasalahan yang ada dalam soal, kesalahan dalam melakukan operasi hitung.

Adapun pada tahap penerapan metode latis, siswa belum memahami dengan baik konsep cara penyelesaian operasi perkalian dengan cara bersusun, dan siswa kurang teliti dalam menjumlahkan dan menuliskan hasil perkalian. 


\section{DAFTAR PUSTAKA}

Arianto. (2015). Upaya Mengatasi Kesulitan Siswa dalam Operasi Perkalian dengan Metode Latice Multiplication di SD 101891 Simpang Penara Kecamatan Tanjung Morawa. Jurnal Pendidikan Matematika, 9(3). 1-5.

Basuki, R. (2011). Analisis Kesalahan Siswa dalam Menyelesaikan Soal Matematika dan Tindak Lanjutnya. (Tesis). UPI, Bandung.

Djadir, \& Darwis, M. (2016). Analisis Kesalahan Siswa pada Operasi Hitung Campuran Bilangan Bulat dan Alternatif Pemecahannya. Jurnal Pendidikan Matematika, 4(1). 1-2.

Haling, Abdul. (2017). Belajar dan Pembelajaran. Makassar: Badan Penerbit Universitas Negeri Makassar.

Mujib, A. \& Suparingga, E. (2013). Upaya Mengatasi Kesulitan Siswa Dalam Operasi Perkalian dengan Metode Latis. Jurnal Pendidikan Matematika, 9(4). 1-6.

Panji. (2017). Pengaruh Penggunaan Metode Latis Terhadap Hasil Belajar Peserta Didik Kelas V SD Islam Hidayatullah pada Materi Operasi Perkalian Pecahan Desimal Mata Pelajaran Matematika. (Skripsi). Universitas Islam Negeri Walisongo: Semarang.

Soedjadi. (2013). Prosedur Penelitian Suatu Pendekatan Praktif. Jakarta: Rineka Cipta.

Wicaksono, F.P., \& Prihatnani, E. (2017). Metode latis sebagai altenatif untuk mengatasi ketidakberhasilan siswa kelas VII SMPN 8 Salatiga dalam menghitung perkalian dengan metode bersusun. Jurnal Pendidikan Matematika, 1(2). 6-15

Yamin, M. (2018). Deskripsi Kesulitan Menyelesaikan Soal Cerita Matematika Siswa Kelas VII SMP Negeri 1 Tellusiattinge Kabupaten Bone. (Skripsi). Universitas Negeri Makassar: Makassar

Zubaidah, \& Kresnadi, H. (2015). Peningkatan hasil belajar matematika dengan metode lattice di kelas III sekolah dasar. Jurnal Pendidikan Guru Sekolah Dasar. 2(4). 1-17 